unpleasant consequences. Zone 2 has a time scale of 1 week and is the valley or town where a persistent inversion traps the air; when such zones occur oxides of nitrogen and hydrocarbon vapours are serious factors. Such zones are not often critical in European conditions. Zone 3 is the whole atmosphere; carbon monoxide has a detectably higher concentration in the northern hemisphere than in the southern hemisphere because there are more cars, but it is being removed continuously in the tropopause and does not build up. There is some evidence that lead from car exhausts is building up globally and a US commission has recommended that there be no further increase in the rate of output of lead.

Dr M. J. A. Hoare (Ricardo and Co. Ltd) described the present and proposed legal restrictions in the United States and Europe and pointed out that Britain and Italy are the only European countries without legislation. The proposed European regulations restrict carbon monoxide and hydrocarbon emission, but not as severely as the present US restrictions. Dr P. Draper (consultant, formerly of Shell-Mex and BP Ltd) suggested that it should be made compulsory for all vehicles marketed in the United Kingdom to meet a revised British standard specification which stipulates a maximum smoke emission at all engine throughputs well below the just visible level. He showed how the average carbon monoxide emission per petrol engine could be reduced to an acceptable level in the United Kingdom with a better carburettor or with fuel injection equipment. Check tests which should show not more than 3.5 per cent carbon monoxide should be made by garages using relatively inexpensive $\mathrm{CO}$ meters under hot idling conditions. Dr G. P. Richard (Esso Research Ltd) showed how the hydrocarbon in the exhaust can reach 1 per cent on the over-run, and said that careful control of air fuel ratio and of spark timing can meet European requirements for a long time and will meet US standards until 1974. Operation with lean mixture, however, even with fuel injection will not give the very low $\mathrm{CO}$ and $\mathrm{C}_{n} \mathbf{H}_{m}$ emissions demanded in the United States by 1975 , so that thermal reactors or catalytic after burners will be necessary. Recycle of exhaust gas will also prove useful for the control of nitric oxide emissions.

Dr D. Barker (BP Research) described the oxide catalysts which are liable to break up and some work on platinum catalysts was also described. Dr A. Lyon (Calor Gas Ltd) showed how far propane could solve the problems associated with carburetion of liquid fuels and also described its use at full rating for the top 30 per cent of the fuel supply of a diesel engine to reduce smoke emission. Dr P. E. Bright (Shell Research Centre) concluded that the spark ignition engine would provide the most acceptable system up till 1980, but that the motorist might have to pay up to 50 per cent more to meet the US pollution requirements. Dr T. Weedon (British Leyland Motor Corporation) said that at the moment a very elaborate experimental system could nearly reach the 1975 test requirements for a short time only.

Dr I. M. Khan (CAV Ltd) gave a fundamental study of smoke formation in the diesel cylinder, the basic factors being the dwell time of the fuel in the over rich region and the temperature. Speeding up the mixing and using earlier injection, and water addition could all greatly reduce smoke at full power. Dr C. Young (Ford Motor Co.
Ltd) described the very extensive laboratory being built at Dunton to carry out 20,000 emission tests on cars a year under European and American conditions. Dr G. Rice (University of Reading) said that the Sterling engine was the only one now capable of meeting the standards proposed for the United States in 1980 and Dr J. W. Todd (Texaco Ltd) described a very interesting stratified charge engine which can give 20 per cent fuel saving, use any fuel (so no lead is necessary) and has very complete combustion with low $\mathrm{NO}_{\mathrm{x}}$.

Professor Thring concluded that Britain can achieve a reasonable compromise by instituting tests to ensure (a) that in spark ignition engines the ignition timing and carburettor performance are of a high standard, and (b) that in diesels, there is good mixing and fuel injection timing.

\section{Significance of Ophiolites}

Although, thanks largely to palaeomagnetism, a great deal is now known about the large scale evolution of the Earth's surface over the past 200 million years or so (that is, since the onset of continental drift in the Wegenerian sense), knowledge of preTriassic activity on the continental and oceanic scale is rather more shaky. The reason for this is obvious, of coursethe mists of time become thicker with age ; but the point is worth making if only to counterbalance the confidence inspired by the successes of the past decade in tracing the progress of continental drift and sea floor spreading during the Mesozoic and Cainozoic. The fact is that very little is known about the configurations of continents and oceans during the Palaeozoic, let alone the Precambrian; and what evidence there is often seems to be conflicting.

The evolution of the AppalachianCaledonian Orogen is a good case in point. The evidence is such that it has been possible to formulate several different models for the origin and history of this system; but as so often happens in geology no firm decision can be made in favour of any of them. In next Monday's Nature Physical Science, however, Bird et al. point to at least one important property of the Appalachian-Caledonian system-the existence of ophiolites - which they claim points some way towards its origin. As Dewey et al. (J. Geophys. Res., 75, 2625 ; 1970) concluded some time ago, there is evidence to suggest that ophiolite complexes were originally oceanic crust and mantle generated by accretion at plate margins (oceanic ridges) and in marginal oceanic basins.
If this is so it clearly becomes important to look closely at what ophiolite sequences exist within the AppalachianCaledonian system. Accordingly Bird and his colleagues have compiled a list of basic and ultrabasic rocks in this system which they believe to belong to the Appalachian-Caledonian ophiolite suite.

Most of the ophiolites that Bird et al. list are known, or suspected, to be Ordovician except for two examples in Newfoundland which must be older and are, in fact, probably Cambrian. The fact that Ordovician ophiolites preponderate has apparently led some workers to suppose that the protoAtlantic Ocean (a former ocean which existed within the area of the present Appalachian-Caledonian Orogen and which coincided roughly with the position of the present central and north Atlantic but which had completely closed by the end of the Devonian) originated during the early Ordovician. With this interpretation Bird and his colleagues disagree. They adduce evidence, for example, which requires the existence of an ocean during the Cambrian and which implies the presence of continental margins during the late Cambrian-early Ordovician Grampian orogeny. Moreover, the older ophiolites in Newfoundland suggest some proto-Atlantic sea floor spreading during the Cambrian. In an alternative interpretation Bird et al. conclude, with evidence, that the proto-Atlantic Ocean actually began to grow during the late Precambrian. This is then consistent with the supposition that the early Ordovician Appalachian-Caledonian ophiolites were the result of lower Palaeozoic sea floor spreading. 